\title{
Contextual Influences on Deliberate Self-harm Among Chinese University Undergraduates: A Representative Nationwide Study
}

\section{Sihui Peng}

Jinan University https://orcid.org/0000-0003-0660-537X

\section{Weifang Zhang}

Zhejiang University

\section{Tingzhong Yang ( $\nabla$ tingzhongyang@zju.edu.cn )}

Center for Tobacco Control Research, Zhejiang University School of Medicine, Hangzhou 310052, China https://orcid.org/0000-0001-8234-0938

\section{Randall R. Cottrell}

University of North Carolina

lan R.H. Rockett

West Virginia University

\section{Research}

Keywords: Deliberate self-harm, nonsuicidal self-injury, contextual factors, unemployment, mental stress, China

Posted Date: October 23rd, 2020

DOl: https://doi.org/10.21203/rs.3.rs-95749/v1

License: @ (i) This work is licensed under a Creative Commons Attribution 4.0 International License. Read Full License 


\section{Abstract}

Background: Numerous studies have identified factors associated with deliberate self-harm (DSH), but environmental influences have been largely neglected. This study explored regional and university contextual factors impacting DSH among undergraduate students in China.

Methods: In this observational cross-sectional study, subjects were 5,016 undergraduate students, who were identified through multistage survey sampling in 22 Chinese universities. Individual-level data were obtained through a self-administered questionnaire, and environmental variables were extracted from the National Bureau of Statistics database. Multilevel logistic regression models were used to examine regional correlates of DSH.

Results: The overall prevalence of self-reported DSH in the study sample was 7.5\% (95\% Cl: $4.1 \%, 10.9 \%)$. The full multilevel logistic model showed university rank and city size were inversely associated with DSH prevalence (OR: 0.24 and 0.55 ). Regional unemployment rates were positively associated with DSH prevalence (OR: 1.98).

Conclusion: Results yield important insights on the role of context in DSH among Chinese undergraduates, and indicate the need to consider environmental factors in order to ameliorate the problem.

\section{Background}

Deliberate self-harm (DSH) is defined as the deliberate, direct destruction or alteration of body tissue without conscious suicidal intent and suicidal behavior [1]; alternatively described as nonsuicidal selfinjury. Research has confirmed that DSH is not only identified frequently among patients with psychiatric diagnoses, but also occurs in nonclinical populations, especially adolescents and young adults[2, 3].In addition to causing physical pain, DSH impacts affect, interpersonal relationships, and academic performance[4]. DSH has emerged as a major social and public health issue among young adults. Many studies have reported characteristics associated with DSH, including sociodemographics, behavioral and mental problems, and social support [5-7]. These studies, however, mainly focused on individual-level factors. Although some studies discerned environmental variation in the prevalence of DSH, they were confined to a very small number of relevant predictors [8-10]. No studies have examined how both individual and environmental factors contribute to DSH variation. The current study examined the independent influence of environmental factors on DSH, especially regional factors. More specifically, it identified variables related to DSH among Chinese undergraduate students, and assessed the extent to which DSH was affected by contextual factors independent of personal characteristics. According to the 'breeder hypothesis,' exposure to environmental factors and physical, social, and behavioral factors may directly or indirectly impact personal health $[11,12]$.

\section{Hypotheses}


Several studies associated individual socioeconomic status with DSH [13, 14],but no previous research has examined the association between regional socioeconomic status and DSH. In this study, we evaluated the hypothesis that both individual-level and regional socioeconomic status were associated with DSH among Chinese undergraduates. We also explored the independent influence of city size and university rank upon DSH among this group. Large cities generally have richer social resources and better technology and public facilities than do smaller ones and more geographically remote cities or smaller communities in China [15]. We measured city size by absolute population rather than by population density or areally. It is plausible that students residing in highly populous and generally opportunity-rich cities endure less stress than do other students, which in turn could translate into a lower prevalence of DSH. Similar to large cities, high-rank universities feature more social and financial resources, better provision for knowledge and skills acquisition, and more employment opportunities than do low-rank universities. Students attending such institutions may therefore experience lower stress levels, and hence engage in less DSH than counterparts in other universities. We hypothesized that both city size and university rank were positively associated with DSH.

Unemployment was another contextual variable examined in this study. Many studies have reported an association between personal psychological stress and DSH [5, 16], and a study by Morgan and colleagues found personal unemployment was also associated [17]. However, these studies excluded regional factors. An unemployment designation requires not only that a person is without work but is also actively seeking it [18]. High unemployment reflects discontinuities in economic growth and structure, a confluence of forces that may stress residents. One study found an association between regional unemployment and violence among women [19]. In concert, the aforementioned findings indicate that high unemployment may be a determinant of DSH.

\section{Methods}

\section{Procedure, subjects and data source}

This was an observational cross-sectional, multilevel study with a multi-staged sampling design. Subjects comprised 5,016 undergraduate students, who came from 22 universities across China. This study reports individual data from the Global Health Professions Student Survey (GHPSS) on Tobacco Control in China GHPSS (Extended version). Compared to the original survey, the extended version included extra health, mental stress, and behavioral items. A detailed description of study methods is reported by Yang et al [20].The individual-level variables were augmented by regional variables, which were extracted from the National Bureau of Statistics database [15, 21].

\section{Measures}

\section{Dependent variable}

Deliberate self-harm (DSH): Survey respondents were asked "In the past year have you ever intentionally harmed yourself without suicidal intent and behavior?" Affirmative answers were classified as DSH [22- 
25].

\section{Individual-level independent variables}

All respondents provided the following sociodemographic information: age, sex, race/ethnicity, grade, major, parental occupation, annual household income, and family residence. Mental stress was measured using the Chinese version of the Perceived Stress Scale (CPSS) $[25,26]$.This scale comprises 14 items that address perceptions of stress during the month prior to the survey. Items were rated on a 5-point Likert-type scale, and ranged from 0 (never) to 4 (very often). We summed item scores to yield a total stress score, with higher scores indicating higher perceived levels of stress. Severe stress was operationalized as a score greater than 25 , following prior practice $[25,26]$.

\section{Contextual independent variables}

University rank was distinguished using the China University Ranking System ("high," "medium," and "low"), as established by the National Ministry of Education [27]. Differential levels implied variable resources, opportunities, and learning environments. There were several independent variables that reflected potential regional variation. The first was degree of economic development, as measured by Gross Domestic Product (GDP) per capita in Yuan. Also included in our analyses were GDP per capita in the province of origin (home province GDP), and GDP per capita in the city where the students resided (university city GDP). Additional contextual variables were the population of the city in which the university was located, and the unemployment rate expressed as the number of unemployed persons per one million population. We extracted the preceding data from the National Bureau of Statistics [16, 22].

\section{Data Analysis}

All data were entered into a database using Microsoft Excel. The dataset was then imported into SAS (9.3 version) for the statistical analyses. Our descriptive outcome measure was prevalence of DSH. A logistic model was utilized to assess associations between the independent variables and the outcome, selfreported self-harm versus no harm. Both unadjusted and adjusted multivariable analyses were presented. SAS survey logistic procedures were applied in the unadjusted analysis. Associations were confirmed through application of a multilevel logistic regression model using the SAS GLIMMIX procedure [27]. All analyses accounted for a within-clustering correlation employing the university as the clustering unit. Series models were built for each primary predictor, with adjustment for potentially confounding sociodemographics. We started with the Null Model, a three-level (individual, university, and city) model with random intercepts, in building the DSH multilevel logistic regression model. To the null base, we added individual, university, regional variables as fixed main effects to form the "individual model", "university model," and "region model" for evaluating environmental impact on DSH. For this analysis, we operationalized the variable "DSH" as a binary response (no $=1$, yes $=2$ ). The first category enumerated for each variable served as the referent in the logistic regression analysis. We assessed the significance of the random parameter variance estimates using the Wald joint $t$ test statistic [28]. 
All statistical analyses were weighted. Weights comprised (1) sampling weights, as the inverse of the probability of selection, calculated at the university level, and (2) post-stratification weights, calculated relative to sex, based on estimated distributions from a national survey [29]. The final overall weights were computed as the product of the preceding weights [28]. We did not consider using a non-response weight since non-response rates were very low. Unadjusted logistic regression analyses were weighted using the overall participant-level weights, and multilevel analysis was weighted using sampling in regional level, subject-level weights were used post-stratification weights, respectively [28].

\section{Results}

Valid questionnaires were completed by $97.7 \%$ of targeted students, resulting in a sample of 5,016 subjects representing 22 universities. Of the sample, $12 \%$ were younger than 20 years of age, $38 \%$ were 20 or 21 , and the remainder 22 years or older. Forty-one percent were male. The majority of subjects $(68 \%)$ were freshmen and sophomores, and $32 \%$ juniors or seniors. Ninety-one percent were Han Chinese (Table 1). 
Table 1

Sample demographic characteristics and prevalence of deliberate self-harm in Chinese undergraduates

\section{Group}

Age (years)

$<20$

20

21

22

$23+$

Gender

Male

Female

Race/ethnicity

Han

Minority

Grade

$1-2$

$3-4$

$5+$

Major

Medical

Others

Paternal occupation

Worker/farmer/merchant

Administrator/clerk

Technical personnel/educator

Maternal occupation

Worker/farmer/merchant

Administrator/clerk $n \quad \%$ of

sample
Prevalence

(\%)
Unadjusted Odds Ratio
1.00

$1.01(0.78,1.57)$

$2.04(0.79,5.24)$

$2.11(0.44,10.02)$

$1.43(0.49,4.17)$

$\begin{array}{lll}971 & 26.7 & 6.5\end{array}$

8.4

1.00

$1617 \quad 41.1$

6.9

$0.81(0.45,1.43)$

$3399 \quad 58.9$

$4548 \quad 90.5$

7.1

1.00

436

9.5

11.5

$1.63(0.90,2.93)$

$2688 \quad 67.9$

8.7

1.00

$2188 \quad 30.8$

4.9

$0.58(0.34,0.97)$ *

$142 \quad 1.3$

4.4

$0.48(0.29,0.81)$ *

$4446 \quad 24.5$

7.4

1.00

$570 \quad 75.5$

7.5

$1.02(0.56,1.85)$

$4092 \quad 71.1$

8.3

1.00

$631 \quad 15.8$

7.1

$0.92(0.64,1.32)$

293

13.1

3.6

$0.42(0.06,2.69)$

$4148 \quad 68.0$

7.8

1.00

$545 \quad 15.5$

4.2

$0.58(0.19,1.78)$ 


\begin{tabular}{|c|c|c|c|c|}
\hline Group & $\mathbf{n}$ & $\begin{array}{l}\% \text { of } \\
\text { sample }\end{array}$ & $\begin{array}{l}\text { Prevalence } \\
(\%)\end{array}$ & $\begin{array}{l}\text { Unadjusted Odds } \\
\text { Ratio }\end{array}$ \\
\hline Technical personnel/educator & 292 & 16.5 & 9.2 & $1.27(0.76,2.12)$ \\
\hline \multicolumn{5}{|l|}{$\begin{array}{l}\text { Annual household income per } \\
\text { capita }\end{array}$} \\
\hline$<10,000$ yuan & 1181 & 34.3 & 7.2 & 1.00 \\
\hline 10,000 & 1273 & 21.7 & 6.1 & $0.82(0.44,1.52)$ \\
\hline $20,000+$ & 1932 & 44.0 & 8.5 & $1.17(0.82,1.69)$ \\
\hline \multicolumn{5}{|l|}{ Student monthly expenditure } \\
\hline$<1,000$ yuan & 347 & 5.4 & 6.0 & 1.00 \\
\hline $1,000-1,499$ & 2717 & 47.9 & 7.0 & $1.17(0.56,2.45)$ \\
\hline $1,500-1,999$ & 1532 & 32.4 & 8.5 & $1.40(0.67,2.93)$ \\
\hline $2,000+$ & 420 & 14.3 & 7.5 & $1.31(0.43,4.02)$ \\
\hline \multicolumn{5}{|l|}{ Mental stress } \\
\hline No & 2590 & 62.3 & 5.4 & 1.00 \\
\hline Yes & 2424 & 33.6 & 10.9 & $2.01(1.36,2.94)^{\star \star}$ \\
\hline \multicolumn{5}{|l|}{ Smoking } \\
\hline No & 4563 & 86.3 & 6.5 & 1.00 \\
\hline Yes & 452 & 13.7 & 14.0 & $2.34(1.56,3.51)^{\star \star}$ \\
\hline \multicolumn{5}{|l|}{ Family residence } \\
\hline Rural & 3350 & 59.6 & 8.5 & 1.00 \\
\hline City county & 768 & 17.2 & 5.6 & $0.68(0.25,1.86)$ \\
\hline City & 898 & 23.2 & 6.3 & $0.78(0.48,1.26)$ \\
\hline \multicolumn{5}{|l|}{ University variable } \\
\hline \multicolumn{5}{|l|}{ Rank } \\
\hline Low & 698 & 8.1 & 20.3 & 1.00 \\
\hline Medium & 2497 & 35.8 & 8.9 & $0.54(0.37,0.47)^{\star \star}$ \\
\hline High & 182 & 53.4 & 4.7 & $0.19(0.16,0.21)^{\star \star}$ \\
\hline \multicolumn{5}{|l|}{ Regional variables } \\
\hline Origin region GDP per capita & & & & \\
\hline
\end{tabular}




\begin{tabular}{|lllll|}
\hline Group & $\mathbf{n}$ & $\begin{array}{l}\text { \% of } \\
\text { sample }\end{array}$ & $\begin{array}{l}\text { Prevalence } \\
(\%)\end{array}$ & $\begin{array}{l}\text { Unadjusted Odds } \\
\text { Ratio }\end{array}$ \\
\hline$<50,000$ yuan & 3367 & 76.3 & 8.0 & 1.00 \\
\hline $50,000-99,999$ & 798 & 12.0 & 5.6 & $0.63(0.31,1.26)$ \\
\hline 100,000 & 851 & 11.7 & 6.1 & $0.88(0.49,1.59)$ \\
\hline University GDP per capita & & & & \\
\hline$<50,000$ yuan & 1382 & 20.3 & 8.4 & 1.00 \\
\hline $50,000-99,999$ & 3103 & 74.6 & 7.4 & $0.95(0.47,1.90)$ \\
\hline 100,000 & 531 & 5.1 & 5.7 & $0.69(0.38,1.26)$ \\
\hline City population(millions) & & & & 1.00 \\
\hline$<1$ & 2644 & 35.5 & 11.4 & $0.64(0.33,1.26)$ \\
\hline $1-3$ & 1398 & 15.0 & 7.6 & $0.41(0.24,0.70) \star \star$ \\
\hline $4+$ & 974 & 49.6 & 4.6 & 1.00 \\
\hline Unemployment rate (per million) & & & & $1.25(0.72,2.19)$ \\
\hline$<100$ & 2086 & 63.5 & 5.9 & $4.08(2.89,5.99) \star \star$ \\
\hline $100-199$ & 1477 & 21.8 & 7.4 & 19.7 \\
\hline $200+$ & 968 & 7.1 & & \\
\hline
\end{tabular}

Of students completing the survey, $7.5 \%$ reported DSH behaviors ( $95 \% \mathrm{Cl}: 4.1-10.9 \%)$. The unadjusted logistic analysis showed grade level, mental stress, smoking, university rank, city size, and unemployment rate were associated with self-reported DSH. The full multilevel logistic model showed that individual grade level, mental stress, and smoking rates were associated with $\mathrm{DSH}$. Turing to the contextual variables, undergraduates residing in cities with fewer than one million people manifested a 1.81 times higher likelihood of reporting DSH than counterparts residing in cities of four million or more. Undergraduates at low-rank universities had 4.14 times the likelihood of reporting DSH than did students in high-rank institutions. Undergraduates residing in regions with a high unemployment rate had approximately twice the self-reported prevalence of DSH as counterparts residing in areas with a low rate (Table 2). 
Table 2

Odds ratios and associated $95 \%$ confidence intervals for an outcome of deliberate self-harm versus no harm in Chinese undergraduates

\begin{tabular}{|c|c|c|c|c|}
\hline & $\begin{array}{l}\text { Null } \\
\text { Model }\end{array}$ & $\begin{array}{l}\text { Model } 1 \\
\text { (Individual) }\end{array}$ & $\begin{array}{l}\text { Model } 2 \\
\text { (University) }\end{array}$ & $\begin{array}{l}\text { Model } 3 \\
\text { (Regional) }\end{array}$ \\
\hline Group & & OR $(95 \% \mathrm{Cl})$ & OR $(95 \% \mathrm{Cl})$ & OR $(95 \% \mathrm{Cl})$ \\
\hline \multicolumn{5}{|l|}{ Grade } \\
\hline $1-2$ & & 1.00 & 1.00 & 1.00 \\
\hline $3-4$ & & $\begin{array}{l}0.64 \\
(0.41,0.98)^{*}\end{array}$ & $0.69(0.40,1.21)$ & $\begin{array}{l}0.67(0.40 \\
1.12)\end{array}$ \\
\hline $5+$ & & $\begin{array}{l}0.61 \\
(0.40,0.93)^{*}\end{array}$ & $\begin{array}{l}0.83(0.76 \\
0.97)^{\star}\end{array}$ & $\begin{array}{l}0.58(0.42 \\
0.81)^{\star \star}\end{array}$ \\
\hline \multicolumn{5}{|c|}{ Mental stress } \\
\hline No & & 1.00 & 1.00 & 1.00 \\
\hline Yes & & $\begin{array}{l}2.17 \\
(1.49,2.70)^{\star \star}\end{array}$ & $\begin{array}{l}1.56(1.19 \\
2.04)^{\star \star}\end{array}$ & $\begin{array}{l}1.67(1.30 \\
2.12)^{\star \star}\end{array}$ \\
\hline \multicolumn{5}{|l|}{ Smoking } \\
\hline No & & 1.00 & 1.00 & 1.00 \\
\hline Yes & & $\begin{array}{l}2.49 \\
(1.52,3.12)^{\star \star}\end{array}$ & $\begin{array}{l}2.17(1.39 \\
3.37)^{\star \star}\end{array}$ & $\begin{array}{l}2.21(1.43 \\
3.42)^{\star \star}\end{array}$ \\
\hline \multicolumn{5}{|c|}{ University ranking } \\
\hline Low & & & 1.00 & \\
\hline Medium & & & $0.55(0.40,0.76)^{\star \star}$ & \\
\hline High & & & $0.24(0.21,0.27)^{\star \star}$ & \\
\hline \multicolumn{5}{|c|}{ City population (millions) } \\
\hline$<1$ & & & & 1.00 \\
\hline $1-3$ & & & & $\begin{array}{l}0.87(0.54 \\
1.40)\end{array}$ \\
\hline $4+$ & & & & $\begin{array}{l}0.55(0.42 \\
0.72)^{\star \star}\end{array}$ \\
\hline \multicolumn{5}{|c|}{ Unemployment rate (per million) } \\
\hline$<100$ & & & & 1.00 \\
\hline $100-199$ & & & & $\begin{array}{l}0.96(0.63 \\
1.47)\end{array}$ \\
\hline
\end{tabular}




\begin{tabular}{|lllll|}
\hline & $\begin{array}{l}\text { Null } \\
\text { Model }\end{array}$ & $\begin{array}{l}\text { Model 1 } \\
\text { (Individual) }\end{array}$ & $\begin{array}{l}\text { Model 2 } \\
\text { (University) }\end{array}$ & $\begin{array}{l}\text { Model 3 } \\
\text { (Regional) }\end{array}$ \\
\hline $200+$ & & & & $1.98(1.48$ \\
\hline Fixed parameters & $9.55^{\star *}$ & $7.44^{\star *}$ & $7.22^{\star \star}$ & $6.77^{\star \star}$ \\
\hline $\begin{array}{l}\text { Random parameters } \\
\text { between universities }\end{array}$ & $2.31^{\star}$ & $2.28^{*}$ & $2.05^{\star}$ & 1.56 \\
\hline $\begin{array}{l}\text { Random } \\
\text { parameters between university } \\
\text { cities }\end{array}$ & $5.04^{\star *}$ & $4.67^{*}$ & $4.17^{\star}$ & 1.87 \\
\hline
\end{tabular}

\section{Discussion}

Approximately $8 \%$ of university undergraduates in this study reported $\mathrm{DSH}$, a lower prevalence than found in other Chinese studies [30,31] but similar to that reported in more economically developed countries $[32,33]$. Further research is necessary to enlighten our finding. We found DSH prevalence varied widely among cities and universities across China, variation that may partially be accounted for by environmental and other contextual variables.

Addressing a gap in the literature, we also found that several contextual variables were associated with self-reported DSH. University undergraduates, who resided in cities of less than one million, approached an almost two-fold higher likelihood of reporting DSH than counterparts in cities of four million or more. Large Chinese cities usually have more social and financial resources than do midsize and small cities [16].Thus, as consequence, it seems plausible undergraduates in large cities have less stress, and in turn the smallest prevalence of DSH. Similarly, undergraduates studying at low-rank universities showed 4fold higher likelihood of reporting DSH than did students in high-rank institutions. Low-rank universities usually have less government financial support, and fewer quality courses and student opportunities [27]. Higher stress experienced by students in response to these deficient living and learning environments may in turn induce more DSH $[6,17]$. Neither regional socioeconomic status nor personal income was associated with DSH. However, university rank and city size showed inverse associations, pointing to the importance of social and economic resources as determinants of DSH [34, 35].These resources are inequitably distributed across China. The more elite universities concentrate in large cities, particularly along the eastern coast. Our research results argue for the need to augment resources for undergraduates in lower rank universities, and contract intercity differences resources in order to reduce DSH.

Undergraduates residing in high unemployment regions approached twice the self-reported prevalence of DSH as counterparts residing in low unemployment regions. Regional unemployment rates are inversely associated with level of economic development, labor absorption capacity, and social stability. Characteristics associated with unemployment, including lack of jobs, low pay, and excess frustration and hopelessness about future employment prospects[36], likely foster a stressful environment for undergraduates. We also found high personal mental stress was associated with self-reported DSH, 
affirming findings from other studies that examined individual-level determinants [6, 17]. Parenthetically, we report a significant interaction between individual mental stress and regional employment status (Estimate: 0.2141, SE: 0.0889), World Chi-Square: 5.80, p: 0.0160).

\section{Study limitations}

Study limitations included the cross-sectional design, which precluded us from assessing causation between individual and regional variables, on the one hand, and DSH, on the other. Serving as mitigating forces, we employed a large sample and our findings met several criteria for inferring causality, including the strength of some associations, their consistency, and plausibility of effect. Future studies need to compile longitudinal surveillance data on DSH. Our subjects were confined to university undergraduates, thus inhibiting generalizability of results to the wider student population and to the Chinese population.

\section{Conclusion}

Contextual disparities appear to contribute to DSH among Chinese undergraduates. Study results point to the need to consider environmental factors in DSH prevention and reduction. Preventive initiatives must focus on redressing imbalances in the allocation of social and economic resources across universities and regions, but include teaching undergraduates how to reduce and manage their mental stress.

\section{Abbreviations}

DSH: Deliberate self-harm

GHPSS: Global Health Professions Student Survey

CPSS: Perceived Stress Scale

GDP: Gross Domestic Product

\section{Declarations}

\section{Ethics approval and consent to participate}

The study was approved by the Ethics Committee at the Medical Center, Zhejiang University, and verbal consent was obtained from all participants prior to data collection.

\section{Consent for publication}

The authors listed the manuscript participated in the work and have agreed to publish this manuscript.

\section{Availability of data and material}


Data sharing not applicable to this article because the datasets we used belongs to our Centre for Tobacco Control Research Zhejiang University School of Medicine. Please contact corresponding author for data requests.

\section{Competing interests}

The authors declare that they have no competing interests.

\section{Funding}

This study was partly funded by the National Nature Science Foundation of China (71490733, 71473221), Global Bridges/IGLC (2014SC1), and Center for Tobacco Control Research, Zhejiang University School of Medicine. This project universities, local government and Center for Disease Control and Prevention also partly fund this survey. These funding was used for the design of the study and collection, analysis, and interpretation of data and in writing the manuscript.

\section{Authors' contributions}

Tingzhong Yang conceived the study design, conceptualized the ideas, and supervised the data management and analyses. Sihui Peng and Weifang Zhang organized the data collection, processed and managed the project. TY wrote the initial manuscript. RC and IR provided the revision of the manuscript. All authors reviewed previous drafts. All authors read and approved the final manuscript.

\section{Acknowledgements}

We thank local teams from the "Facilitate $\mathrm{MOH}$ endorsement of tobacco control implementation through promoting tobacco control advocacy capacity in medical schools "(supported by UION)" Project for organizing the data collection. Project universities, local governments and Center for Disease Control and Prevention (CDC) all provided financial support for this survey.

\section{References}

1. Gratz K L. Risk factors for and functions of deliberate self- harm: an empirical and conceptual review. Clinical Psychology: Science and Practice 2003; 10:192-205.

2. Klonsky ED, Oltmanns TF, Turkheimer E. Deliberate self-harm in a nonclinical population: Prevalence and psychological correlates. American Journal of Psychiatry 2003; 160:1501-1508.

3. Laukkanen E, Rissanen ML, Honkalampi K, Kylma J, Tolmunen T, Hintikka J. The prevalence of selfcutting and other self-harm among 13-to 18-year-old Finnish adolescents. Social Psychiatry and Psychiatric Epidemiology 2009; 44: 23-28.

4. Kong X, Liu Y, Liu W. Analysis on correlation between social support and self-injury of undergraduate nursing students. Chinese Nursing Research 2014; 28: 3240-3241. 
5. Su PY, Hao JH, Huang ZH, Tao FB. An investigation on self-harm episodes and their relationship with suicidal psychology and behaviors in 2713 college students. Chinese Journal of Epidemiology 2010; 31: 1267-1271.

6. Muehlenkamp JJ, Gutierrez PM. An investigation of differences between self-injurious behaviour and suicide attempts in a sample of adolescents. Suicide and Life-Threatening Behavior 2004; 34: 12-23.

7. Taliaferro LA, Muehlenkamp JJ, Borowsky IW, McMorris BJ, Kugler KC. Factors distinguishing youth who report self-injurious behavior: A population-based sample. Academic Pediatrics 2012; 12: 205213.

8. Harriss L, Hawton K. Deliberate self-harm in rural and urban regions: a comparative study of prevalence and patient characteristics. Social Science \& Medicine 2011; 73: 274-281.

9. Lloyd-Richardson EE, Perrine N, Dierker L, Kelley ML. Characteristics and functions of non-suicidal self-injury in a community sample of adolescents. Psychological Medicine 2007; 37: 1183-1192.

10. Toprak S, Cetin I, Guven T, Can G, Demircan C. Self-harm, suicidal ideation and suicide attempts among college students. Psychiatry Research 2011; 187: 140-144.

11. Macintyre S, Maciver S, Soomans A. Area, class and health: should we be focusing in places or people? Journal of Social Policy 1993; 22: 213-234.

12. Yang T. Health research: social and behavioral theory and methods.Beijing: People Medical Publishing House, 2018

13. Platt S, Hawton K. Suicidal behaviour and the labour market. In The International Handbook of Suicide and Attempted Suicide. New York: John Wiley \& Sons, 2000.

14. Hawton K, Harriss L, Simkin S, Bale E, Bond A. Social class and suicidal behaviour: the associations between social class and the characteristics of deliberate self-harm patients and the treatment they are offered. Social Psychiatry and Psychiatric Epidemiology 2001; 36: 437-443.

15. Department of Comprehensive Statistics of National Bureau of Statistics. China Statistical Yearbook for Regional Economy. Beijing: China Statistics Press, 2014.

16. Greco V, Roger D. Uncertainty, stress, and health. Personality and Individual Differences 2003; 34: 1057-1068.

17. Morgan HG, Burns-Cox CJ, Pocock H, Pottle S. Deliberate self-harm: clinical and socio-economic characteristics of 368 patients. The British Journal of Psychiatry 1975; 127: 564-574.

18. Thirteenth International Conference of Labour Statisticians. Resolution concerning statistics of the economically active population, employment, unemployment and underemployment In Current international recommendations on labour statistics. Geneva: International Labour Organization, 2002.

19. Yang T, Yang Y, Cottrell RR, Wu D, Jiang S, Anderson JG. Violent injuries and regional correlates among women in China: results from 21 cities study in China. The European Journal of Public Health $2015 ; 26,513-517$. 
20. Yang T, Yu L, Bottorff JL, Wu D, Jiang S, Peng S, Young KJ. Global Health Professions Student Survey (GHPSS) in Tobacco Control in China. American Journal of Health Behavior 2015; 39: 732741.

21. Department of urban social economic survey of the National Bureau of Statistics. China City Statistical Yearbook. Beijing: China Statistics Press, 2014.

22. Warner M, Schenker N, Heinen MA, Fingerhut LA. The effects of recall on reporting injury and poisoning episodes in the National Health Interview Survey. Injury Prevention 2005; 11: 282-287.

23. Koziol-McLain J, Brand D, Morgan D, Leff M, Lowenstein SR. Measuring injury risk factors: question reliability in a statewide sample. Injury Prevention 2000; 6:148-150.

24. Wu D, Rockett IRH, Yang T, Feng X, Jiang S, Yu L. Deliberate self-harm among Chinese medical students: A population-based study. Journal of Affective Disorders 2016; 202: 137-144.

25. Yang TZ, Huang HT. An epidemiological study on stress among urban residents in social transition period. Chinese Journal of Epidemiology 2003; 24: 760-764.

26. Wang $H$, Yang $X Y$, Yang T, Cottrell RR, Yu L, Feng $X$, Jiang S. Socioeconomic inequalities and mental stress in individual and regional level: a twenty one cities study in China. International Journal for Equity in Health 2015; 14: 25.

27. College entrance examination inquires (2015). [Cited 2017 May 10] Available from: http://www.gaokao.com/baokao/lqfsx/ybfsx/.

28. Wang J, Xie H, Jiang B. Multilevel models: Methods and application. Beijing: Higher Education Press, 2008.

29. National Ministry of Education. Annual report on university graduates' employment in 2015. [Cited 2017 Sep 15] Available from: http://news.sohu.com/20131107/n389748218.shtml/.

30. Qiao H, Chen Y. An investigation of non-suicidal self-injury and coping styles in undergraduates. Journal of Psychiatry 2012; 25: 436-439.

31. Wan YH, Gao R, Tao XY, Tao FB, Hu CL. Relationship between deliberate self-harm and suicidal behaviors in college students. Chinese Journal of Epidemiology 2012; 33: 474-477

32. Gollust SE, Eisenberg D, Golberstein E. Prevalence and correlates of self-injury among College students. Journal of American College Health 2008; 56, 491-498.

33. Whitlock J, Eckenrode J, Silverman D. Self-injurious behaviors in a college population. Pediatrics 2006; 117, 1939-1948.

34. Corcoran P, Arensman E, Perry IJ. The area-level association between hospital-treated deliberate selfharm, deprivation and social fragmentation in Ireland. Journal of Epidemiology and Community Health 2007; 61: 1050-1055.

35. Gunnell DJ, Peters TJ, Kammerling RM, Brooks J. Relation between parasuicide, suicide, psychiatric admissions, and socio-economic deprivation. British Medical Journal 1995; 311: 226-230.

36. Lou XJ, Zhou SH, Wu LY. Analysis of college students' employment. Research in Educational Development 2005; 13: 49-52. 